\title{
ON CERTAIN MEDICAMENTOUS SYNERGIAS IN INDUCED "BIÓCEMESIS" (ARTIFICIAL HIBERNATION)
}

\author{
Bernard Paradis, M.D., Roger Brault, M D , Paul Sirois, M.D., \\ Robert NAUd, M D., and Armand Lamontagne, M.D. *
}

THE expression "medicamentous synergia" means the use of products whose pharmacodynamic properties act together, enhancing or completing one another - "potentializing one another" as Huguenard writes (9).

The term "biocemesis" is a new one, characterizing a state of slower life, close to hibernation. It comes from the Greek and is literally the acton of wearing away. We borrowed it from Colonel Jaulmes, because it best expresses the type of anaesthesia which we are going to present; that is to say, a decrease of the neurovegetative life, obtained solely with drugs and the utilization of cold. We are edging away more and more from the purely sensory anaesthesia, which often produces shock and shows adrenalin-like effects, such as ana esthesia with ether. We are therefore aiming towards anaesthesia with few or no anaesthetics, towards anaesthesia of the reflex arc, and towards a neuro-humoral and a neuro-endocrine anaeșthesia (pituitary, adrenal, and thyroid).

The idea is not new. It was not conceived strictly from intuition, but is the result of the study of the problem of "shock," which for years has disturbed research workers. Claude Bernard brought forward the notion of the "internal milieu"; Cannon spoke of "homeostasis," and Leriche of "postoperative disease." Reilly and Selye, in demonstrating the nature of organic responses to aggression, featured the neurovegetative system and the neuro-humoral (endocrine) system.

It is mainly to Professor H. Laborit of the Military Hospital of Val-de-Grâce, Paris, that we owe a good symposium resulting from all the previous ideas and from subsequient research work. Laborit has published extensively on this subject $(10,11,12,13,14,15)$, and he and his associates have summarized the state of this question in all fields of medicine. In 1953, Professors Hudon and Jacques also presented a study of the problem of hibernation (8). All these studies would seem to revolutionize certain concepts not only of anaesthesia, but also of various aspects of medicine and therapeutics as a whole.

Let us take as examples to illustrate this evolution the premature baby, and the baby born in a state of duress. It has always been classical to treat premature infants by combating cooling with the aid of incubators. We act in exactly the same way when we deal with babies born in a state of duress due to cerebral anoxia following a hard delivery, prolonged compression of the cord, or manoeuvres of forced traction. In both cases, these babies are placed in an incubator and covered with very warm clothes, which scarcely give them the necessary freedom to breathe The resulting picture is always the same:- hyperthermia, profuse sweating, polypnea, tachypnea, atelectasis, convulsions, cyanosis, and very often death.

'St. François d'Assise Hospital, Quebec City. 
Now let us describe the clmical picture of two of our recent cases. They are baby $\mathrm{P}$ - and baby $\mathrm{M}--$ born at an interval of one hour, both after a very difficult delivery. Both of them were revived only after intubation, oxygen therapy, and respiratory stimulants given intravenously, all this taking one hour before the first spontaneous respiration. Both eventually showed the syndrome previously described, 1.e. hyperthermia consecutive to cerebral anoxemia.

Baby $\mathrm{M}$ - is placed in an incubator, has on too many clothes, and is given too much heat. He sweats profusely, his temperature rises to $106^{\circ} \mathrm{F}$., in the 36 hours following his birth He dies within 48 hours, literally "consumed."

Baby $\mathrm{P}-$ is placed in the same room $\mathrm{He}$ is just laid in bed and is given oxygen. Within 8 hours, his temperature has already risen to $105^{\circ} \mathrm{F}$. and he also manifests stiffness in the neck and convulsive episodes. To the horror of the medical personnel, the baby is cooled down to $96^{\circ} \mathrm{F}$. in a tent with ice, under a concentration of 40 per cent oxygen. The baby is naked. He receives $2.5 \mathrm{mg}$. of Phenergan intramuscularly every 5 hours, $5 \mathrm{cg}$. of Gardenal every 6 or 8 hours and subcutaneous serum. After seven days of this treatment baby $\mathrm{P}--$ is removed from the tent. He is alive and can have some nourishment.

We do not wish to make a general conclusion after only two cases, but we do wish to state that babies born with the syndrome of hyperthermia as well as premature infants would perhaps benefit more not by heating, but by cooling after neuroplegia. As David states, it would be preferable to hibernate them in order to help them pass through this critical period of their commencement of life.

The problem is the same for the premature infant. He is a tiny being not capable of raising or mantaining his metabolism to the indispensable level which would assure his thermogenesis, his tissue life, and his growth. Very often, the application of very warm conditions to reduce the difference between his capabilities and his needs is a complete failure. Let us, then, consider the question of cold for premature babies.

We should consider the premature baby as suffering from "shock" and as $\mathrm{at}$ patient in whom, according to Laborit, "in decreasing the tissue needs, one; could expect to create a new equilibrum through which the organism could acquire its normal functional state, not recuperate as does the adult."

Again, we do not pretend to solve the problem by mentioning two casual cases, - but we wish to present the viewpoint that hibernation is applicable to the premature infant as well as to the baby born with cerabral anoxia.

The human being has developed and improved himself, and, by so doing, has acquired freedom in relation to external stales. He does not adapt himself any more to environment but tends to adapt these external conditions to his own requirements. He has improved his defence mechanism by conditioning his autonomic nervous system, visceral and hormonal, which evolves independently of his individual will.

The higher being evolves according to an imaginary equilibrium called "Health," with constant oscillations which are not noticeable as long as they do not exceed the defence limit of the organism. However, any attack on this mean is considered as an aggression against which the organism reacts in a very specific 
and very well-defined way. Disease is an aggression. Trauma is an aggression. Surgical intervention is an aggression which may lead to operative disease and death, by exhaustion of the reactive capabilities of the organism.

The well-evolved being reacts to aggression by increasing his combustion and his exchange in opposing to the maximum this environment in which he is and which is aggressive to him. Therefore, there is a certain wavering around his lost equilibrium, a biocatalytic wavering in which calcium, potassium and all electrolytes take a part. Histamine, acetylcholine, adrenalin, gluco- and mineralocorticoids, and all endocrine secretions also play their part.

To summarize, any surgical operation constitutes an aggression against the organism. Following this aggression there is a phase of immediate disequilibrium -a phase of more or less severe shock commensurate with the severity of the aggression. The organism, through its autonomic nervous system and its chemical agents (of which adrenalin comes first), reacts to this state of immediate shock by a catabolic phase, i.e through adrenalin, then through the pituitary gland with gluco-protidic incidence on the adreno-cortex. This phase lasts four to five days on the average. It is a sympathicomimetic phase, destructive to the proteins. It may cause thrombosis and prevents cicatrisation. Then comes the anabolic phase of compensation which is vagal, acetylcholiric, and characterized by its mineralocorticoids. This passage from the adrenalinic state to the vagal one is very often marked by grave accidents: it is the vagal crisis of the fourth or fifth day following operation, with hypotension, lipothymia, cold sweating, infarctoid accidents, and at times collapse and embolic accidents. T'owards the end of this period, that is from the sixth to the tenth day, the balance is re-established. The protein rate comes back to normal, appetite is felt again by the patient, and the weight increases. All the digestive functions resume their activities.

Such is the picture following operation as we see it: at present. We have borrowed it from the synthesis of Laborit, and after ten years of clinical research work aiming at a neuro-vegetative equilibrium in anaesthesia, we have come to the same conclusions as Laborit and his associates.

Endocrinologists and biologists also agree on such an explanation of shock and we feel it will prove advantageous to carry on experimental work on the same line.

Laborit uses a pituitary somatotrope extract called Somatrophine (S.T.H.) in general surgery, in order to counteract the action of the adreno-corticotrope pituitary hormone. With this hormone, he wishes to accomplish on the endocrinological plan what is realized with Largactil on the pharmacodynamic one. The idea is the following. The patient who is hibernated, in a state of "slower life," with a lowered metabolism, does not use his hydrocarbons, but does utilize his proteins and his lipids. Somatrophne is employed to reduce the use of protides, to prevent the utilization of glucose, and to mobilize the catabolism of lipids. Thus, it is not only the neuro-humoral activity which is depressed but also the neuro-endocrine activity.

We have not yet had the opportunity of using this hormone but we take the precaution of injecting proteins intravenously in cases of hydration occurring during or after operation, in order to combat this protein deficit of the plasma and thus to avoid lumbar bed-sores in patients immobilized for a long time. 
Let us now describe what we are doing and what research workers have brought about in the field of anaesthesia. We shall see whether or not the condition of the patients has been improved and if so, in what way.

In routine surgery, cases of total hibernation, either pharmacodynamic or hypothermic, are rather unusual. However, what we may call semi-hibernation is often practised, meaning that a neuro-vegetative balance is established on the day preceding the operation and is terminated in the first few hours following it.

Every aggressive action calls for a counter-reaction which is as strong or disastrous as the aggression has been violent. If we succeed in decreasing or, if possible, in suppressing this aggressive action at its very onset, we thus decrease the counter-reaction. This idea may apply to any case of surgery.

The problem varies with the facilities of each anaesthetist. In our hospital, we had to eliminate what seemed to be the complicated points of the technique and aimed at the most practical method for our patienls, that is to say, at the suppression of the aggression at its starting point and hence, at the prevention of shock. We attempt.

1. The suppression of the emotional aggression by a visit to the patient before the operation and then the elimination of anxiety through persuasion and premedication during the day or days preceding the operation.

2. The suppression of the aggression during the operation by blocking all the possible irritations from the afferent pathways of the reflex arc, the centres, and the efferent pathways. This blockade is carried on during the day or days following the intervention

With this object in mind, we utilize the following pharmacological products in appropriate fashion:

(a) Barbiturates such as Carbrital, Pentothal and Surital.

(b) Antihistaminics such as Phenergan and Beriadryl.

(c) Neuroplegics such as Largactıl or-Neocaine and Methonium salts.

(d) Analgesics such as Demerol.

(e) Curarizing agents such as Syncurine and Flaxedil.

Postoperatively we use Sparteine in patients free from troubles of auriculoventricular conduction, Magnesium Sulfate, Prostigmine, and Demerol. We do not use Atropine which is "antibiocemetic." Induction barbiturates, such as Pentothal or Surital, are used only as starters and as a rule the dose never exceeds $350 \mathrm{mg}$., whatever the duration of the operation.

One of the products to which we wish to draw attention is the derivative of Phenothiazine, R.P. 3277 (Promethazine or Phenergan or Fargan or dimethylamino-2'-methyl-2'-ethyl-N-dibenzo parathiazine hydrochloride.) This product possesses pharmacodynamic properties and promotes actions which are most valuable:

1. Blockade of the afferent pathway of the reflex arc (therefore, suppression at its starting point of surgical irritation caused either by manipulation or traction, and thus a decrease in the counter-reaction).

2. Hypnotic and amnesic action.

3. Antalgic action.

4. Hypometabolic action.

5. Antibiotic action. 
6. Anti-shock action by the diminution of capillary permeability, by the reestablishment of the pre-capillary sphincter action, and by the diminution of the chemo-sensitivity of the carotid glomus.

7. Diuretic action through diminution of the sensisivity of renal tubules.

8. Inhibitor hypophysial action.

9. Anti-emetic and antihistaminic action.

We use Phenergan intramuscularly as premedication, during the operation we use it intravenously, diluted in a solution containing either Largactil ( R P. 4560), Neocaine or a Methonium salt, and Demerol. We also use it postoperatively by the intramuscular route and more rarely by the intravenous route. The average daily doses range between 200 and $250 \mathrm{mg}$.

The pharmacological properties of Demerol, Procaine, Largacti (R.P. 4560) and other Phenothiazine derivatives are all well known. The - henothiazine derivatives have become the symbol of pharmacodynamic hiberna ion. We will not enlarge upon their pharmacodynamy.

Let us now analyse the picture of a patient undergoing rather a serious surgical operation.

During the night preceding the operation, he sleeps following $100 \mathrm{mg}$. of Benadryl and $1 \frac{1}{2}$ to 3 grains of Carbrital, which exerts a sedative action on the cortex.

On the morning of the intervention, the patient will receive, by the intramuscular route, $50 \mathrm{mg}$. of Phenergan and $100 \mathrm{mg}$. of Demerol; or he wll be given a barbiturate, $1 \frac{1 / 2}{\mathrm{hr}}$. before the operation, and, just $1 \mathrm{hr}$. before, an intravenous infusion of a solution containing $50 \mathrm{mg}$. of Largactil, $50 \mathrm{mg}$. of Phenergan, and $100 \mathrm{mg}$. of Demerol.

When he is taken to the operating room, he is in a state of complete lobotomisation. During the operation, the operative shock is combatted with these products whilst a close supervision is kept of the electrolyte, protein, and blood balance. The barbiturate doses for the induction of the anaesthesia are small. An adequate and constant curarization is maintained during the whole intervention. All the patients are intubated. The control of respiration is a routine. During the operation, the heart is controlled by the electronic cardioscope and the central and peripheral temperatures are controlled by a thermocouple.

Leaving the operating room, the patient is in a unique state of twilight sleep, which will not prevent him from answering questions, but which will keep him amnesic to all the following infusions. In normal postoperative cases, we keep on injecting $50 \mathrm{mg}$. of Demerol together with $1 \mathrm{cc}$. of prostigmine $(1: 1200)$, as required.

Sparteine and Magnesium Sulfate are injected if necessary. We have been using these products for a year and a half.

We have noticed the following inconveniences:

1. Dryness of mouth, lips and tongue.

2. Elimination or diminution of hydrochloric acid in the stomach, and therefore stomach pains at the awakening.

3. The patient cannot get up from bed as early after operation, and at times manifests agitation, due to this medicamentous lobotomy. 
4. Closer supervision is necessary.

5. Drainage of the bladder with a catheter is almost obligatory.

In spite of these inconveniences, we, and our medical personnel, could see the following advantages:

1. Use of narcotics is decreased 90 per cent.

2. Meteorism, distension, dilatation of stomach, intestinal flatulence, and vomiting are almost completely eliminated.

3. The electrolyte balance is noore easily maintained.

4. Pulmonary complications are prevented.

5. Postoperative embolus or postpartum phlebitis are absent. There are marked advantages. The necessity for getting up from bed early is eliminated. Considering that adrenalin (as digitaline) blocks the secretion of heparin at the mast cells, if we eliminate the adrenergic phase we thus favour the increase of heparinemia and therefore the decrease of prothrombin time. In our opinion, this is a most valuable advantage.

6 Finally, the temperature during operation, controlled by the thermocouple, is lowered by three or four degrees $F$., compared to a rise of one to three degrees F. during usual anaesthetic procedure.

Let us summarize a few clinical observations:

(a) Mrs. A.P.B., 65 years of age, undergoes a laparotomy for total hysterectomy, double salpingo-ovariectomy, appendicectomy, and cholecystectomy for a calculous subacute cholecystitis. All this surgery was performed during one intervention. The patient received the usual premedication, i.e. Carbrital, Phenergan, Demerol. The administration of solution No. 1 containing $50 \mathrm{mg}$. of Largactll, $50 \mathrm{mg}$ of Phenergan, and $100 \mathrm{mg}$. of Demerol, duluted in $500 \mathrm{cc}$. of 5 per cent glucose serum, was started three-quarters of an hour before the

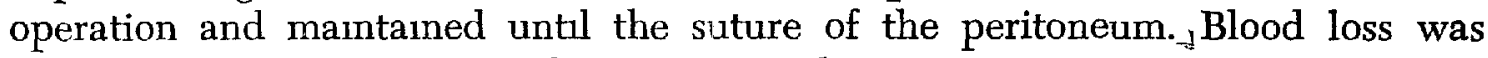
evaluated at $300 \mathrm{cc}$. Durang the operation, the patient received only $200 \mathrm{mg}$. of Pentothal for induction and $8 \mathrm{mg}$. of Syncurme, plus oxygen and nitrous oxide mhaled through the endotracheal tube. Following the operation, the patient was given only $50 \mathrm{mg}$. of Phenergan intramuscularly every sixth or eighth hour, for $72 \mathrm{hr}$. No narcotic was administered, the patient did not suffer from any nausea, vomiting, or distension and the third day, when Phenergan was stopped, the bowels functioned normally. She got up Irom bed and did not complain of any pain.

(b) M.O.D., 68 years old, underwent a cholecystectomy for acute calculous cholecystitis. This is a case similar to the previous one. After the operation, the patient had only $50 \mathrm{mg}$. of Phenergan injected intramuscularly every $6 \mathrm{hr}$. He does not remember anything from the eve of the operation to the third day when he was allowed to get up. The central temperature never rose more than one degree. Although obese and weighing more than two hundred pounds, and a plethoric, the patient had a most normal recovery.

(c) Miss Y.D., 20 years old, has to undergo a ligature of the arterial canal. Unlike the first two patients, this one receives solution No. 2 containing Phenergan, Demerol, and Neocaine. During the intervention, there is no alteration of the hemodynamics or of the electrocardiogram. Only $225 \mathrm{mg}$. of Pentothal 
are given and a curarizing agent in the total amount of $9 \mathrm{mg}$. Following the operation, she is given $50 \mathrm{mg}$. of Phenergan with $25 \mathrm{mg}$. of Largactil intramuscularly every $8 \mathrm{hr}$. No narcotic is administered.

(d) Mrs. Y.M., 86 years old, underwent an arthroplasty of the left ankle. Solution No. 4 was injected before and during the intervention. As a sedative, she received only $50 \mathrm{mg}$. of Phenergan every $8 \mathrm{hr}$. Recovery was normal.

(e) M.G.D. after severe trauma is taken to the hospital in a state of complete shock. It is completely impossible to detect the pulse or the arterial pressure. His face is livid and waxy. Treatment for shock is begun immediately. Two hours later the surgeon is willing to perform an operation. The arterial tension is stll not percervable and the pulse rate is 140 per minute. Solution No. 4 is injected before anaesthesia. One hundıed milligrams of Pentothal associated with $4 \mathrm{mg}$. of Syncurine allow an easy intubation. The control of respiration is started. The surgeon is very surprised to notice that even before any injection other than solution No. 4, the arterial tension has risen to $100 \mathrm{~mm}$. $\mathrm{Hg}$. The patient undergoes splenectomy for rupture of the spleen, left nephroplasty because of laceration, and dramage of a serious retroperitoneal hematoma. Recovery was satisfactory.

(f) Baby L- , one month old, undergoes a laparotomy for grafting of the common bile duct. The diagnosis is atresia of the biliary ducts. As a premedication; the baby receives $21 / 2 \mathrm{mg}$. of Phenergan and $21 / 2 \mathrm{mg}$. of Largactil by the intramuscular route. Durmg the intervention only a curarizing agent is administered and a mixture of oxygen, nitrous oxide given through an endotracheal tube which allows controlled respiration. The patient is cooled to $32^{\circ} \mathrm{C}$. During the intervention which lasts about three hours, his condition remains excellent. The cooling is maintained for three days. No post-operatıve sedative is given.

We have mentioned this last case to point out the importance of combining neuro-vegetative anaesthesia and hypothermia at times. This baby would have not survived such a serious operation with the old methods of strictly sensory anaesthesia.

Technically speaking we do not follow standard rules, but adapt the abovementioned drugs to the needs of the individual, according to his physical condition and to the severity of the surgical operation.

Personally, we have agreed to use five different intravenous muxtures for "biocemesis," which we designate as follows.

$S^{1}$ stands for a solution containing $100 \mathrm{mg}$. of Demerol, $50 \mathrm{mg}$ of Largactil, $50 \mathrm{mg}$. of Phenergan, diluted in a 5 per cent glucose solution.

$\mathrm{S}^{2}$ stands for a solution containing $50 \mathrm{mg}$. of Phenergan, $100 \mathrm{mg}$. of Demerol, and $1 \mathrm{gm}$. of Neocaine.

$\mathrm{S}^{3}$ contains $50 \mathrm{mg}$. of Phenergan, $40 \mathrm{mg}$. of a Methonum salt, and $100 \mathrm{mg}$. of Demerol.

$\mathrm{S}^{4}$ contains $50 \mathrm{mg}$. of Phenergan and $1 \mathrm{gm}$. of Necicaine.

$\mathrm{S}^{5}$ contains only $50 \mathrm{mg}$. of Phenergan.

We use one or the other of these solutions according to the surgical intervention to be performed.

We have used Phienergan (R.P. 3277 or Promethazine) during 2,175 operations, 
including gastrectomies, pancreato-duodenectomies, bysterectomies, ligatures of the arterial canal, Caesarean sections, and vaginal deliveries. Phenergan was the most used of all the hibernating drugs, etther for premedication, during the operation, or after the operation.

Solution No. 1 was used for 165 cases, with 254 for solution No. 2, 28 for No. 3, 112 for No. 4, and 160 Jor No. 5 .

Let us summarize these observations in the following comments:

In our opinion, any anaesthetist who wishes to use this tech ique must study it very carefully beforehand and know exactly the pharmacology of each one of the drugs involved.

If we seem to have particularly stressed the cautious and logical utilization of Phenergan (R.P. 3277) and Largactil (R.P. 4560) in each case, it is because our experimental work has shown that these products allow us to decrease the amount of barbiturates, narcotics, or anaesthetics used previously.

Phenergan is not as delicate to manipulate as its cousin Largactil, and may easily be applied to every medical field.

As to Largactil, we must recognize its action on the central nervous system, its sedative, hypnotic, hypothermic properties as well as its action on the autonomic nervous system and its gangloplegic properties One must not forget the potentiating action of Largactil on Procaine

It is not necessary to use all the hibernating drugs at the same time, but rather according to the severity of the surgical intervention and to the physical condition of the patient

The uthlization of drugs capable of blocking the transmission and the action of the neuro-vegetative impulse has greatly improved the general state of our anaesthetized patients.

Through potentalized anaesthesia, we were able to improve anaesthesia during and following the operation.

A greater organic protection was obtamed against surgical aggression.

The use of narcotics and barbiturates was reduced considerably and, in many patients, totally abandoned.

In conclusion, may we add that the nicest and truest testimonial of this progress in anaesthesia is the observation of many patients that "to be operated upon now is not as hard, painful and complicated as it used to be."

In fact, it is now possible for us to promise the patient that he will be able to go through a surgical intervention without anxiety, without vomiting, without shock, and that he will come out of it without any incident.

\section{RÉSUMÉ}

Le terme "Biocemese" est un néologisme du médecin-colonel Jaulmes, de Paris, et indique un état de vie rallentie par l'usage de médicaments seulement sans l'apport du froid

L'auteur préconise l'anesthésie neuro-végétative pour remplacer l'ancienne anesthésie strictement sensitive, dans le but de prévenir le shoc opératoire, l'agression chirurgicale, et d'améliorer les suites post-opératoires. C'est le résultat 
des travaux de Relly et de Selye, et des expérimentations de Laborit et de Huguenard.

L'auteur décrit les techniques utilisées au cours de son expérimentation, et les propriétées des produits utılisés et insiste sur le R.P. 3277 ou Phenergan et sur le R.P 4560 ou Largactil. Il décrit les avantages et inconvénıents de la technique, les précautions à prendre et illustre ses données par la présentation de cas cliniques typiques. Ses résultats, sur 719 cas au moment de la publication, sont des plus prometteurs.

\section{REFERENCES}

1 Allaume, R. Les différents degrés de l'hibernation artıficielle Anesth et analg. 9261 (1952).

2 BADre, G. Chirurgie et hibernation artificielle. Anesth. et analg 1152 (1954).

3 Cahn, J, Melon, J M, \& Dubrasquet, M Le cœur sous hibernation artificielle. Anesth. et analg 10420 (1953)

4. Camn, J, Dubrasquet, M, Bodiou, J, \& Melon, J. M. Méthodes d'hibernation artificielle- étude expérımentale comparée. Anesth, et analg. 11: 141 (1954).

5. Cookson, B. A, Neptune, W B., \& Barty, C. P. Hypothermia as a means of perform.1ng Intracardiac Surgery under Direct Vision Dis , of Chest 22245 (1952).

6 Dogliotri, A M. \& Ciacatto (Turin). Les bases physio-pathologiques de l'hypothermie et les possibilités de l'association hypothermie-circulation extra-corporeale. Lyon chir. 49. 19 (1954).

7. Foy, $\mathrm{T}$ Observation on Prolonged Human Refrigeration. New York State J. Med. 40. 1351 (1940).

8 Hudon, Fernando \& Jacques, André. Artuficial Hibernation Proc Canad Anaesth Soc. (1953).

9 Huguenaro, P Hibernation artificielle-nouvelle données utıles Anesth et analg 9. 240 (1952).

10 Laborit, $H$, Jaulmes, C, \& Benitte, A. Quelques aspects expérimentaux de l'hıbernation artuficielle. Anesth et analg 9232 (1952).

11 Laborit, H. \& Huguenard, P Pratıque de l'hibernothérapie en chirurgie et en médecine Paris Masson (1954).

12 LaBonrt, H. L'anesthésie facilitée par les synergies médicamenteuses. Paris (1951).

13. LaboRit, H. Réaction organıque à l'aggression et au choc. Parıs (1952).

14. LABorit, $H$ Résistance et soumission en physiobiologie: l'hibernation artificielle. Paris Masson (1954)

15 Labonit, H. Sur la physio-pathologie et le traitement de gelures Presse méd 601256 (1952).

16. Lazorthes,' G \& Campane, L. (Toulouse). L'évolution anesthésiologique en chirurgie cérébrale. Anesth, et analg. 11: 1 (1954).

17 Lazonthes, G. Le système neuro-vasculaure. Parıs (1949).

18 Melon, J. M. Pharmacodynamie cardio-vasculare sous hibernation artificielle. Semame d'information sur l'hibernation artificielle, Parıs (24 février, 1953).

19. Rieunau, J. L'hibernation dans les neuro-toxicoses du nourrisson. technique et résultats Anesth. et analg. 10. 331 (1953).

20. Worminger, E., Schnemer, J, Baumgartner, J., \& Thomalske, G. Essai critique sur l'effet de l'hibernation artıficielle sur dix-neuf cas de souffrance du tronc cérébral après traumatısme sélectıonnés pour leur gravité parmi deux cent soixante-dix comas postcomotionnels. A'nesth. et analg. 11. 34 (1954).

21. Zeavin, I., Virtue, R, \& Swan, H. Cessation of Circulation in General Hypothermia Anesthetic Management. Anesthesiology 15.113-22 (1954). 